\title{
GERMINAÇÃO E VIGOR DE SEMENTES DE CENOURA OSMOCONDICIONADAS EM PAPEL UMEDECIDO E SOLUÇÃO AERADA ${ }^{1}$
}

\author{
MÁRCIO DIAS PEREIRA², DENISE CUNHA FERNANDES DOS SANTOS DIAS ${ }^{3}$, LUIZ ANTONIO DOS SANTOS DIAS ${ }^{3}$ e EDUARDO \\ FONTES ARAÚJO3
}

\begin{abstract}
RESUMO - Na cultura da cenoura são constantes os problemas relativos ao desempenho das sementes no campo, justificando-se o uso de técnicas que acelerem a germinação das sementes e a emergência das plântulas. O objetivo do trabalho foi avaliar o efeito do condicionamento osmótico na germinação e no vigor de sementes de cenoura, utilizando-se dois métodos de embebição. Para tanto, sementes de dois lotes, cv. Brasília, foram condicionadas em soluções de PEG 6000 a -1,0 e -1,2 MPa por quatro e oito dias, a $20^{\circ} \mathrm{C}$, utilizando-se dois métodos: embebição em papel toalha umedecido com as respectivas soluções e imersão em soluções osmóticas aeradas. Sementes não condicionadas foram utilizadas como testemunha. Após, as sementes condicionadas ou não, foram avaliadas por meio dos testes: de germinação, primeira contagem de germinação, emergência das plântulas em campo aos 10 e 25 dias após a semeadura e comprimento de raiz primária. Verificou-se que o condicionamento osmótico em PEG 6000 por quatro dias foi efetivo em aumentar a porcentagem e a velocidade de germinação, bem como a emergência das plântulas em campo. Para o crescimento da raiz primária, o condicionamento osmótico em solução aerada em PEG 6000 a -1,2MPa foi superior ao tratamento em papel.
\end{abstract}

Termos para indexação: Priming, vigor de sementes, Daucus carota L.

\section{GERMINATION AND VIGOR OF CARROT SEEDS PRIMED IN MOISTENED PAPER AND AERATED SOLUTION}

\begin{abstract}
The problems regarding carrot seeds performance in the field are constant justifying the use of techniques to accelerate germination and seedling emergence. The objective of this study was to evaluate the effects of two imbibition methods during priming on carrot seed germination and vigour.. Two seed lots of carrot, Brasília cultivar, were primed in PEG 6000 -1.0 and -1.2MPa solutions for 4 and 8 days, at $20^{\circ} \mathrm{C}$, using two imbibition methods: paper towel moistened with the respective solutions and immersion in aerated osmotic solutions. Non-primed seeds were used as control. The seeds were submitted to the following tests: germination, first count, percentage and speed of seedling emergence in the field at 10 and 25 days after sowing and primary root length. Priming in PEG 6000 for four days was effective in increasing the percentage and speed of germination and seedling emergence in the field. For primary root length, priming in PEG 6000-1.2 MPa aerated solution was superior to moistened paper treatment.
\end{abstract}

Index term: Osmotic conditioning, seed vigor, Daucus carota L.

${ }^{1}$ Submetido em 09/07/2007. Aceito para publicação em 17/03/2008. Parte
da Dissertação de Mestrado do primeiro autor apresentada ao Programa de
Pós-graduação em Fitotecnia/Produção vegetal, UFV. Órgão financiador:
Capes. ${ }^{2}$ Eng. Agrônomo, doutorando do Programa de Pós-graduação em Fitotecnia/Produção vegetal da Universidade Federal de Viçosa, marcioagron@yahoo.com.br; ${ }^{3}$ Prof. do Departamento de Fitotecnia da Universidade Federal de Viçosa - UFV, 36570-000 - Viçosa - MG. 


\section{INTRODUÇÃO}

Para otimizar o estabelecimento das culturas em campo são necessárias sementes de elevada qualidade, capazes de germinarem rápido e uniformemente nas mais diferentes condições edafo-climáticas. Este aspecto se torna mais importante ainda para hortaliças de ciclo curto que são semeadas diretamente no campo, como é o caso da cenoura. Muitas vezes, as condições de clima e solo não favorecem o estabelecimento uniforme das plântulas, gerando falhas no estande que comprometem a produtividade e a qualidade final do produto.

$\mathrm{Na}$ cultura da cenoura são constantes os problemas relativos à qualidade e desempenho das sementes em campo, sendo prática comum entre os produtores, o uso de quantidade excessiva de sementes para posterior desbaste, aumentando os gastos com mão de obra, ou a necessidade de uma nova semeadura, também onerando o custo de produção. Quando são utilizadas semeadoras mecânicas de precisão, que elimina a necessidade do desbaste, o desempenho das sementes em campo torna-se mais relevante ainda.

Nesse contexto, justifica-se o uso de tratamentos que reduzam o tempo necessário entre a semeadura e a emergência das plântulas, resultando em maior segurança quanto à obtenção de populações desejadas de plantas por área, especialmente sob condições adversas. Dentre as técnicas que têm sido estudadas para esta finalidade destaca-se o condicionamento osmótico ou "priming" (Khan et al., 1978; Khan, 1992), que consiste na pré-embebição das sementes em soluções osmóticas ou em água, de modo a permitir a ocorrência das etapas metabólicas iniciais do processo de germinação, sem permitir a protrusão da raiz primária (Heydecker et al., 1975; Khan et al., 1978; Bradford, 1986).

Os tratamentos de condicionamento mais utilizados incluem o osmocondicionamento, que consiste na hidratação em solução osmótica de um composto quimicamente inerte como o polietileno glicol (PEG 6000 ou PEG 8000) ou em solução salina (Heydecker et al., 1975) e o hidrocondicionamento, que envolve a hidratação em água por período específico de tempo (Thornton e Powell, 1995).

Diversos trabalhos têm comprovado que o condicionamento osmótico acelera a germinação, permitindo a emergência mais rápida e uniforme das plântulas no campo (Heydecker et al., 1975; Bradford, 1986). Em sementes de cenoura, os benefícios deste tratamento foram relatados por Haigh et al. (1986), Cantliffe e Elballa (1994), Copeland e McDonald (1995), Lopes et al. (2000), Balbinot e Lopes (2006). Porém, para Nascimento (2004) nem sempre os resultados obtidos com o condicionamento das sementes são positivos, havendo ainda necessidade de se expandir os conhecimentos sobre diferentes aspectos relacionados com esta técnica, como o método mais apropriado para se fazer a aeração das sementes.

Sabe-se que muitos são os fatores que determinam o sucesso do condicionamento osmótico, podendo-se citar a qualidade inicial das sementes (Nascimento e Aragão, 2002), o período e a temperatura de condicionamento, o potencial osmótico da solução (Evans e Pill, 1989), bem como o agente osmótico (Bradford, 1986), cuja eficiência varia entre as espécies (Welbaum et al., 1998). Também o método de condicionamento pode influenciar no sucesso da técnica (Caseiro et al., 2004; Marcos Filho, 2005). Quando são utilizadas substâncias de alto peso molecular e quimicamente inertes como o PEG, pode ser necessário um sistema de aeração artificial durante o condicionamento, pois a solubilidade do oxigênio é inversamente proporcional à concentração do soluto (Heydecker e Coolbear, 1977). No entanto, não há consenso quanto aos efeitos desta aeração no resultado do tratamento. Para Guedes e Cantliffe (1980), a aeração da solução reduziu o tempo necessário para o condicionamento de sementes de alface, sendo esse tratamento também recomendado por Bradford et al. (1986) e Nascimento (2003) para sementes de hortaliças, enquanto Akers et al. (1985) constataram seu efeito deletrério. Além destes fatores, a adição de fungicidas à solução osmótica tem sido recomendada para inibir o desenvolvimento de microorganismos (Khan et al., 1992), pois existem diversos relatos sobre aumento na incidência de fungos em sementes osmocondicionadas (Maude et al., 1992; Nunes et al., 2000).

O objetivo deste trabalho foi avaliar o efeito do condicionamento osmótico na germinação e no vigor de sementes de cenoura, utilizando-se dois métodos de embebição.

\section{MATERIAL E MÉTODOS}

O trabalho foi desenvolvido no Laboratório de Pesquisa de Sementes do Departamento de Fitotecnia, da Universidade Federal de Viçosa, no período de janeiro a setembro de 2006. Foram utilizados dois lotes comerciais de sementes de cenoura (Daucus carota L.), variedade Brasília, apresentando 70\% e $76 \%$ de germinação e teor de água de $12 \%$ e $10 \%$ (lotes 1 e 2 , respectivamente). 
As sementes de cada lote foram condicionadas osmoticamente em solução de polietileno glicol 6000 (PEG 6000) com potenciais osmóticos ajustados a $-1,0 \mathrm{e}-1,2 \mathrm{MPa}$, de acordo com Villela et al. (1991), à temperatura de $20^{\circ} \mathrm{C}$, por períodos de quatro e oito dias. A cada solução foram acrescidos $0,15 \%$ de ingrediente ativo do produto comercial Captan 750 TS 24, objetivando controlar o desenvolvimento de fungos. Sementes não condicionadas foram utilizadas como controle.

Foram utilizados dois métodos de condicionamento:

- Embebição em papel umedecido: conduzido em caixas gerbox, onde 4,0g de sementes de cada lote, em duas subamostras de 2,0g, foram distribuídas em camada única sobre duas folhas de papel toalha umedecidas com $4,5 \mathrm{~mL}$ das soluções de PEG 6000, sendo esse volume suficiente para cobrir metade da espessura das sementes, ficando parte da superfície exposta à atmosfera do interior das caixas. As caixas foram tampadas, envolvidas em sacos plásticos para evitar perdas por evaporação, e mantidas em incubadora $\mathrm{BOD}$ a $20^{\circ} \mathrm{C}$.

- Imersão em solução aerada: neste método, $4,0 \mathrm{~g}$ de sementes foram colocadas em erlenmeyers (capacidade $250 \mathrm{~mL}$ ) contendo $40,0 \mathrm{~mL}$ da solução de $\mathrm{PEG}$, na proporção de 1:10 (semente:solução). Os erlenmeyers foram vedados com rolha de borracha, supridos com aeração constante por meio de uma bomba de ar (bomba de aquário) e mantidos em incubadora $\mathrm{BOD}$ a $20^{\circ} \mathrm{C}$.

Após quatro e oito dias de condicionamento em ambos os métodos, as sementes foram lavadas durante um minuto em água corrente. Em seguida, foi determinado o grau de umidade pelo método da estufa a $105^{\circ} \mathrm{C}$ por 24 horas (Brasil, 1992). As sementes foram colocadas para secar sobre duas folhas de papel toalha, em ambiente de laboratório (em torno de $20^{\circ} \mathrm{C}$ ), até atingirem o teor de água inicial, cerca de $12 \%$ para o lote 1 e $10 \%$ para o lote 2 .

A seguir, as sementes de cada lote e tratamento foram submetidas aos seguintes testes:

Germinação: utilizaram-se quatro repetições de 50 sementes distribuídas sobre duas folhas de papel toalha, umedecidas com volume de água destilada equivalente a três vezes o peso do papel seco e dispostas em caixas plásticas (tipo gerbox) que foram mantidas em germinador a $20^{\circ} \mathrm{C}$. Avaliou-se a porcentagem de plântulas normais aos sete e quatorze dias após a semeadura (Brasil, 1992). Emergência de plântulas em campo: a semeadura foi feita em fevereiro de 2006, em canteiros com as dimensões de $1,0 \mathrm{~m}$ de largura e $5,0 \mathrm{~m}$ de comprimento em área experimental do Departamento de Fitotecnia da UFV, em Viçosa, MG. As sementes de cada tratamento foram distribuídas em quatro sulcos espaçados de $5,0 \mathrm{~cm}$ entre si, com profundidade de aproximadamente $1,0 \mathrm{~cm}$. Para cada lote e tratamento, 200 sementes, em quatro subamostras de 50 sementes, foram distribuídas eqüidistantemente ao longo de cada sulco. A seguir, as sementes foram cobertas com uma camada de solo de cerca de 1,0 cm de espessura. Foram feitas irrigações diárias pelo sistema de aspersão, mantendo o solo suficientemente úmido. Os resultados foram expressos em porcentagem média de plântulas normais emergidas aos 10 e 25 dias após a semeadura. Comprimento de raiz primária: inicialmente, três folhas de papel toalha foram umedecidas com volume de água destilada equivalente a três vezes o peso do papel. Foram utilizadas quatro subamostras de dez sementes, sendo cada subamostra distribuída sobre uma linha reta de $10 \mathrm{~cm}$ traçada ao longo da extremidade superior do papel toalha, de modo que as sementes ficassem distanciadas $1,0 \mathrm{~cm}$ uma da outra. As caixas gerbox foram colocadas no germinador de câmara, à temperatura de $20^{\circ} \mathrm{C}$, em posição inclinada, com um ângulo de $45^{\circ}$, para facilitar o crescimento descendente das raízes, segundo método descrito por Nakagawa (1999). O comprimento médio da raiz primária das plântulas foi determinado ( $\mathrm{cm} /$ plântula) aos quatorze dias após a semeadura. Procedimento estatístico: adotou-se o delineamento inteiramente casualizado, com quatro repetições. Os dados experimentais coletados foram submetidos a testes de normalidade, que indicaram a não necessidade de transformação. As análises de variância foram processadas em esquema fatorial 2 × 2 × 5 ( 2 lotes, 2 métodos de embebição e 5 tratamentos de condicionamento -PEG $-1,0 \mathrm{MPa} / 4$ e 8 dias, $\mathrm{PEG}-1,2 \mathrm{MPa} / 4$ e 8 dias + controle). As médias dos tratamentos foram comparadas pelo teste de Tukey, a 5\% de probabilidade. Todas as análises foram processadas no programa estatístico SAS (1989).

\section{RESULTADOS E DISCUSSÃO}

Para ambos os lotes, os teores de água determinados após o condicionamento osmótico por 4 dias, em PEG 6000 a $-1,0$ e $-1,2 \mathrm{MPa}$, foram de 45 e $43 \%$ (papel) e 49 e $47 \%$ (imersão), respectivamente. Quando se utilizou o período de condicionamento de oito dias, em ambos os métodos, o teor de água das sementes dos lotes 1 e 2 aumentou ligeiramente atingindo valores de $46 \%$ (papel) e $50 \%$ (imersão), respectivamente. Portanto, pode-se considerar que o teor de água das sementes praticamente não variou entre os tratamentos e lotes. A determinação do teor de água 
após o condicionamento osmótico deve ser considerada um importante parâmetro na seleção dos tratamentos a serem empregados (Caseiro et al., 2004).

Pela Tabela 1, verifica-se que o condicionamento osmótico em PEG 6000 por quatro dias, independente do potencial osmótico e do método de embebição, contribuiu para aumentar a porcentagem de germinação das sementes dos dois lotes em até 20 pontos percentuais, chegando a $94 \%$ (lote 1) e $92 \%$ (lote 2). Sementes condicionadas por oito dias tiveram germinação significativamente semelhante à da testemunha. Resultados semelhantes foram obtidos por Carneiro et al. (1999) e Peluzio et al. (1999), que constataram aumento significativo na germinação de sementes de cenoura osmocondicionadas em solução de PEG 6000 a -1,5 MPa por sete dias, ocorrendo redução na germinação quando o período de condicionamento foi aumentado para 14 e 21 dias. Os efeitos benéficos do condicionamento osmótico podem ser alterados pela duração do tratamento, conforme observado para sementes de beterraba (Costa e Vilela, 2006) e cebola (Caseiro e Marcos Filho, 2005) cujo condicionamento reduziu a germinação e o desempenho das sementes nas condições avaliadas. Já Cantliffe e Abede (1993) observaram aumento significativo na porcentagem e velocidade de germinação de sementes de tomate condicionadas em $\mathrm{KNO}_{3}$ por 6,7 e 8 dias, o que não ocorreu quanto o condicionamento durou 4 ou 5 dias.

TABELA 1. Germinação (\%) das sementes de dois lotes de cenoura submetidas a diferentes tratamentos de condicionamento osmótico à $20^{\circ} \mathrm{C}$, utilizando embebição em papel umedecido e em solução aerada (Viçosa - MG, 2007).

\begin{tabular}{|c|c|c|c|c|c|c|}
\hline \multirow[b]{2}{*}{ Tratamentos } & \multicolumn{3}{|c|}{ Lote 1} & \multicolumn{3}{|c|}{ Lote 2} \\
\hline & $\begin{array}{c}\text { Papel } \\
\text { umedecido }\end{array}$ & $\begin{array}{l}\text { Solução } \\
\text { aerada }\end{array}$ & Média & $\begin{array}{c}\text { Papel } \\
\text { umedecido }\end{array}$ & Solução aerada & Média \\
\hline $\begin{array}{l}\text { Testemunha (não } \\
\text { condicionada) }\end{array}$ & $70 \mathrm{Ca}^{1 /}$ & $70 \mathrm{Ca}$ & 70 & $76 \mathrm{BCa}$ & $76 \mathrm{Ca}$ & 76 \\
\hline $\begin{array}{c}\text { PEG } 6000-1,0 \mathrm{MPa} \\
\text { por } 4 \text { dias }\end{array}$ & $93 \mathrm{Aa}$ & $92 \mathrm{ABa}$ & 93 & $92 \mathrm{Aa}$ & $88 \mathrm{ABa}$ & 90 \\
\hline $\begin{array}{c}\text { PEG } 6000-1,0 \mathrm{MPa} \\
\text { por } 8 \text { dias }\end{array}$ & $76 \mathrm{Ca}$ & $79 \mathrm{Ca}$ & 78 & $76 \mathrm{BCa}$ & $78 \mathrm{BCa}$ & 77 \\
\hline $\begin{array}{c}\text { PEG } 6000-1,2 \mathrm{MPa} \\
\text { por } 4 \text { dias }\end{array}$ & $90 \mathrm{ABa}$ & $94 \mathrm{Aa}$ & 92 & $87 \mathrm{ABa}$ & $91 \mathrm{Aa}$ & 89 \\
\hline $\begin{array}{c}\text { PEG } 6000-1,2 \mathrm{MPa} \\
\text { por } 8 \text { dias }\end{array}$ & $78 \mathrm{BCa}$ & $81 \mathrm{BCa}$ & 80 & $74 \mathrm{Cb}$ & $84 \mathrm{BCa}$ & 80 \\
\hline Média & 82 & 84 & 83 & 81 & 84 & 83 \\
\hline
\end{tabular}

Por sua vez, o método de condicionamento não influenciou a germinação das sementes do lote 1, sendo ambos os procedimentos (embebição em papel umedecido e em solução aerada) eficientes (Tabela 1). Já para o lote 2, a germinação das sementes condicionadas em PEG a -1,2 MPa, por oito dias, em solução aerada foi superior à das sementes condicionadas em papel umedecido, diferença esta que não ocorreu nos demais tratamentos.

Os dados médios de germinação na primeira contagem encontram-se na Tabela 2. Sementes que originaram maior porcentagem de plântulas normais na primeira contagem do teste de germinação são mais vigorosas, sendo um indicativo de maior velocidade no processo de germinação (Nakagawa, 1999). Assim como observado para a porcentagem de germinação, o condicionamento osmótico em PEG 6000, por quatro dias, contribuiu para aumentar a velocidade de germinação das sementes do lote 1 , independente do potencial osmótico e do método utilizado, enquanto sementes condicionadas por oito dias não diferiram da testemunha. Gray et al. (1991), também trabalhando com sementes de cenoura, observaram que, quando as sementes foram condicionadas em PEG durante quatorze dias, a velocidade de germinação diminuiu consideravelmente, indicando que períodos mais longos de condicionamento podem ser prejudiciais ao 
desempenho das sementes. Para as sementes do lote 2, em geral, os tratamentos de condicionamento em PEG 6000 a $-1,0 \mathrm{MPa}$, por quatro dias, e a $-1,2 \mathrm{MPa}$, por quatro e oito dias, em ambos os métodos de embebição, foram superiores à testemunha, contribuindo para aumentar a velocidade de germinação das sementes. Peluzio et al. (1999) constataram que a diminuição do potencial osmótico (-1,2 $\mathrm{MPa})$ em interação com um maior período de condicionamento (14 dias) diminuiu de forma expressiva a velocidade de germinação das sementes de cenoura, contrastando com os resultados do presente trabalho onde o maior período (8 dias) aliado à maior concentração da solução de PEG (-1,2 MPa) aumentou a velocidade de germinação das sementes do lote 2 , e não prejudicou a do lote 1 em relação à testemunha.

TABELA 2. Primeira contagem de germinação (\%) das sementes de dois lotes de cenoura submetidas a diferentes tratamentos de condicionamento osmótico à $20^{\circ} \mathrm{C}$, utilizando embebição em papel umedecido e em solução aerada (Viçosa - MG, 2007).

\begin{tabular}{|c|c|c|c|c|c|c|}
\hline \multirow[b]{2}{*}{ Tratamentos } & \multicolumn{3}{|c|}{ Lote 1} & \multicolumn{3}{|c|}{ Lote 2} \\
\hline & $\begin{array}{c}\text { Papel } \\
\text { umedecido }\end{array}$ & $\begin{array}{l}\text { Solução } \\
\text { aerada }\end{array}$ & Média & $\begin{array}{c}\text { Papel } \\
\text { Umedecido }\end{array}$ & $\begin{array}{l}\text { Solução } \\
\text { aerada }\end{array}$ & Média \\
\hline $\begin{array}{l}\text { Testemunha (não } \\
\text { condicionada) }\end{array}$ & $64 \mathrm{Ba}^{1 /}$ & $64 \mathrm{Ba}$ & 64 & $68 \mathrm{Ca}$ & $68 \mathrm{Ba}$ & 68 \\
\hline $\begin{array}{c}\text { PEG } 6000-1,0 \mathrm{MPa} \\
\text { por } 4 \text { dias }\end{array}$ & $90 \mathrm{Aa}$ & $90 \mathrm{Aa}$ & 90 & $90 \mathrm{Aa}$ & $90 \mathrm{Aa}$ & 90 \\
\hline $\begin{array}{c}\text { PEG } 6000-1,0 \mathrm{MPa} \\
\text { por } 8 \text { dias }\end{array}$ & $65 \mathrm{Ba}$ & $67 \mathrm{Ba}$ & 66 & $71 \mathrm{BCa}$ & $69 \mathrm{Ba}$ & 70 \\
\hline $\begin{array}{c}\text { PEG } 6000-1,2 \mathrm{MPa} \\
\text { por } 4 \text { dias }\end{array}$ & $88 \mathrm{Aa}$ & $79 \mathrm{Ab}$ & 84 & $90 \mathrm{Aa}$ & $79 \mathrm{ABb}$ & 85 \\
\hline $\begin{array}{c}\text { PEG } 6000-1,2 \mathrm{MPa} \\
\text { por } 8 \text { dias }\end{array}$ & $67 \mathrm{Ba}$ & $67 \mathrm{Ba}$ & 67 & $80 \mathrm{Aba}$ & $80 \mathrm{Aa}$ & 80 \\
\hline Média & 75 & 74 & 75 & 80 & 78 & 79 \\
\hline CV (\%) & & & & & & \\
\hline
\end{tabular}

Quando são comparados os métodos de condicionamento (Tabela 2), verifica-se, para ambos os lotes, que houve redução na velocidade de germinação apenas das sementes condicionadas em solução aerada de PEG 6000 -1,2 MPa, por quatro dias, em relação àquelas condicionadas em papel umedecido. Neste caso, houve a necessidade de maior tempo de aeração na solução de menor potencial osmótico para se obter o efeito similar ao obtido no tratamento em papel.

Na Tabela 3 observa-se que, em ambos os lotes, praticamente todos os tratamentos de condicionamento contribuíram para aumentar a emergência das plântulas em campo aos 10 dias em relação à testemunha, não havendo diferença significativa entre potencial osmótico da solução e tempo de condicionamento, com exceção do tratamento PEG 6000 a $-1,0 \mathrm{MPa}$, por oito dias, no lote 1 , que não diferiu da testemunha. É importante ressaltar que, a emergência de plântulas das sementes não condicionadas (testemunha) do lote 2 que era de $19 \%$ foi elevada para $70 \%$, após o condicionamento osmótico em papel umedecido com PEG a $-1,2 \mathrm{MPa}$, por quatro dias. Observa-se ainda que, para ambos os lotes, não houve diferença significativa entre os métodos de embebição testados, conforme também constatado pelos resultados de germinação (Tabela 1) e primeira contagem (Tabela 2). Contudo, Heydecker et al. (1975) demonstraram que a aeração da solução osmótica foi essencial para sincronizar a germinação das sementes de hortaliças. Para Parera e Cantliffe (1994), a resposta à aeração durante o condicionamento osmótico varia conforme a espécie, sendo que o período ideal de duração do tratamento pode ser modificado quando se utiliza um sistema de aeração. 
TABELA 3. Emergência (\%) de plântulas em campo, aos 10 dias, de dois lotes de sementes de cenoura submetidas a diferentes tratamentos de condicionamento osmótico à $20^{\circ} \mathrm{C}$, utilizando embebição em papel umedecido e em solução aerada (Viçosa - MG, 2007).

\begin{tabular}{ccccccc}
\hline & \multicolumn{2}{c}{ Lote 1 } & Lote 2 & & \\
Tratamentos & Papel umedecido & $\begin{array}{l}\text { Solução } \\
\text { aerada }\end{array}$ & Média & $\begin{array}{l}\text { Papel } \\
\text { Umedecido }\end{array}$ & $\begin{array}{l}\text { Solução } \\
\text { aerada }\end{array}$ & Média \\
\hline $\begin{array}{c}\text { Testemunha (não } \\
\text { condicionada) } \\
\text { PEG 6000 - 1,0 MPa } \\
\text { por 4 dias }\end{array}$ & $42 \mathrm{Ba}$ & $42 \mathrm{Ba}$ & 42 & $19 \mathrm{Ba}$ & $19 \mathrm{Ba}$ & 19 \\
$\begin{array}{c}\text { PEG 6000 - 1,0 MPa } \\
\text { por 8 dias }\end{array}$ & $64 \mathrm{Aa}$ & $62 \mathrm{Aa}$ & 63 & $68 \mathrm{Aa}$ & $64 \mathrm{Aa}$ & 66 \\
$\begin{array}{c}\text { PEG 6000 - 1,2 MPa } \\
\text { por 4 dias }\end{array}$ & $48 \mathrm{Ba}$ & $44 \mathrm{Ba}$ & 46 & $62 \mathrm{Aa}$ & $58 \mathrm{Aa}$ & 60 \\
$\begin{array}{c}\text { PEG 6000 - 1,2 MPa } \\
\text { por 8 dias }\end{array}$ & $66 \mathrm{Aa}$ & $67 \mathrm{Aa}$ & 66 & $70 \mathrm{Aa}$ & $66 \mathrm{Aa}$ & 68 \\
Média & $69 \mathrm{Aa}$ & $72 \mathrm{Aa}$ & 71 & $68 \mathrm{Aa}$ & $66 \mathrm{Aa}$ & 67 \\
CV (\%) & 58 & 58 & 58 & 58 & 55 & 57 \\
\hline
\end{tabular}

${ }^{1 /}$ Médias seguidas pela mesma letra maiúscula na vertical e minúscula na horizontal, não diferem entre si, a 5\% de probabilidade pelo teste de Tukey.

Na Tabela 4 observa-se, para ambos os lotes, que todos os tratamentos de condicionamento contribuíram para aumentar a emergência das plântulas em campo aos 25 dias em relação à testemunha, não havendo diferença significativa entre potencial osmótico da solução e tempo de condicionamento. Os métodos de embebição não afetaram os resultados do condicionamento das sementes do lote 2; contudo, para o lote 1, em geral, a imersão das sementes em solução aerada resultou em maior emergência de plântulas quando comparada ao método de embebição em papel umedecido, exceto no tratamento PEG 6000 a -1,0 MPa por 4 dias, onde não houve diferença significativa entre os métodos de embebição testados. Efeitos positivos do condicionamento osmótico na emergência de plântulas em campo têm sido relatados para diversas espécies como cebola (Nunes et al., 2000), sorgo (Carvalho et al., 2000); aspargo (Bittencourt et al., 2004) e cenoura (Magalhães et al., 2004).

TABELA 4. Emergência (\%) de plântulas em campo, aos 25 dias, de dois lotes de sementes de cenoura submetidas a diferentes tratamentos de condicionamento osmótico a $20^{\circ} \mathrm{C}$, utilizando embebição em papel umedecido e em solução aerada (Viçosa - MG, 2007)..

\begin{tabular}{ccccccc}
\hline Tratamentos & $\begin{array}{c}\text { Papel } \\
\text { umedecido }\end{array}$ & $\begin{array}{c}\text { Lote } 1 \text { Solução } \\
\text { aerada }\end{array}$ & Média & $\begin{array}{c}\text { Papel } \\
\text { umedecido }\end{array}$ & $\begin{array}{c}\text { Lote } 2 \text { Solução } \\
\text { aerada }\end{array}$ & Média \\
\hline $\begin{array}{c}\text { Testemunha (não } \\
\text { condicionada) }\end{array}$ & $51 \mathrm{Ca}^{1 /}$ & $51 \mathrm{Ca}$ & 51 & $27 \mathrm{Ba}$ & $27 \mathrm{Ba}$ & 27 \\
PEG 6000 - 1,0 MPa & $73 \mathrm{ABa}$ & $71 \mathrm{Ba}$ & 72 & $87 \mathrm{Aa}$ & $82 \mathrm{Aa}$ & 85 \\
$\begin{array}{c}\text { por 4 dias } \\
\text { PEG 6000 - 1,0 MPa }\end{array}$ & $66 \mathrm{Bb}$ & $77 \mathrm{Ba}$ & 72 & $83 \mathrm{Aa}$ & $80 \mathrm{Aa}$ & 82 \\
por 8 dias & $71 \mathrm{ABb}$ & $83 \mathrm{ABa}$ & 77 & $91 \mathrm{Aa}$ & $89 \mathrm{Aa}$ & 90 \\
$\begin{array}{c}\text { PEg - 1,2 MPa } \\
\text { por 4 dias }\end{array}$ & $82 \mathrm{Ab}$ & $94 \mathrm{Aa}$ & 88 & $86 \mathrm{Aa}$ & $89 \mathrm{Aa}$ & 88 \\
$\begin{array}{c}\text { por } 8 \text { dias } \\
\text { Média }\end{array}$ & 67 & 76 & 72 & 75 & 74 & 75 \\
CV (\%) & & & & & &
\end{tabular}

"Médias seguidas pela mesma letra maiúscula na vertical e minúscula na horizontal, não diferem entre si, a 5\% de probabilidade pelo teste de Tukey. 
É importante ressaltar que os resultados positivos do condicionamento osmótico na emergência em campo (Tabelas 3 e 4) também foram confirmados em laboratório pelo teste de germinação (Tabela 1), o que é interessante, pois, muitas vezes, o efeito benéfico do osmocondicionamento na germinação em laboratório pode não se manifestar no campo, como salientam Gimenez-Sampaio e Sampaio (1998) em seus trabalhos com essa mesma espécie. O melhor desempenho, tanto em campo como em laboratório, observado para as sementes condicionadas é explicado por Bradford (1986), que sugere que o condicionamento osmótico promove um acúmulo de solutos nas células no decorrer do processo de embebição, resultando em maior potencial de turgor celular nas sementes, refletindo em rapidez na emergência da raiz primária. Este fato é particularmente importante quando se consideram as condições muitas vezes adversas de clima e solo durante a emergência das plântulas em campo (Trigo et al., 2000). Durante o condicionamento são iniciados vários processos como a mobilização das reservas, ativação e "síntese-de-novo" de enzimas, síntese de DNA e RNA, produção de ATP, além de reparos de danos no sistema de membranas que contribuem para melhorar o desempenho das sementes osmocondicionadas no campo (Bradford, 1986 e Khan, 1992).

O efeito do condicionamento osmótico no comprimento da raiz primária das plântulas de cenoura pode ser observado na Tabela 5. Em geral, para ambos os lotes, o condicionamento das sementes em papel umedecido não contribuiu para o aumento do comprimento da raiz primária, exceto nas sementes do lote 1 condicionadas por quatro dias em PEG a $-1,0 \mathrm{MPa}$, as quais foram superiores à testemunha.

TABELA 5. Comprimento da raiz primária (cm/plântula) de plântulas das sementes de dois lotes de cenoura submetidas a diferentes tratamentos de condicionamento osmótico a $20^{\circ} \mathrm{C}$, utilizando embebição em papel umedecido e em solução aerada (Viçosa - MG, 2007).

\begin{tabular}{|c|c|c|c|c|c|c|}
\hline Tratamentos & Papel umedecido & $\begin{array}{l}\text { Lote } 1 \\
\text { Solução aerada }\end{array}$ & Média & $\begin{array}{c}\text { Papel } \\
\text { umedecido }\end{array}$ & $\begin{array}{l}\text { Lote } 2 \\
\text { Solução } \\
\text { aerada }\end{array}$ & Média \\
\hline $\begin{array}{l}\text { Testemunha (não } \\
\text { condicionada) }\end{array}$ & $7,00 \mathrm{Ba}^{1 /}$ & $7,00 \mathrm{Ca}$ & 7,00 & $5,75 \mathrm{Aa}$ & $5,75 \mathrm{Ca}$ & 5,75 \\
\hline $\begin{array}{c}\text { PEG } 6000 \text { - 1,0 MPa por } \\
4 \text { dias } \\
\text { PEG } 6000-1,0 \mathrm{MPa} \text { por }\end{array}$ & $8,00 \mathrm{Aa}$ & $6,50 \mathrm{Cb}$ & 7,25 & $4,43 \mathrm{Bb}$ & $6,50 \mathrm{Ca}$ & 5,45 \\
\hline $\begin{array}{c}8 \text { dias } \\
\text { PEG } 6000-1,2 \text { MPa por }\end{array}$ & $7,00 \mathrm{Ba}$ & $8,00 \mathrm{Ba}$ & 7,50 & $4,65 \mathrm{Bb}$ & $8,25 \mathrm{Ba}$ & 6,45 \\
\hline 4 dias & $6,50 \mathrm{Bb}$ & $9,25 \mathrm{Aa}$ & 7,87 & $5,25 \mathrm{ABb}$ & $9,00 \mathrm{Aa}$ & 7,12 \\
\hline $\begin{array}{c}\text { PEG } 6000 \text { - 1,2 MPa por } \\
8 \text { dias }\end{array}$ & $6,50 \mathrm{Bb}$ & $9,75 \mathrm{Aa}$ & 8,13 & $5,18 \mathrm{ABb}$ & $10,00 \mathrm{Aa}$ & 7,58 \\
\hline CV (\%) & 7,0 & 8,1 & 7,55 & 5,1 & 7,9 & 6,5 \\
\hline
\end{tabular}

1/Médias seguidas pela mesma letra maiúscula na vertical e minúscula na horizontal, não diferem entre si, a 5\% de probabilidade pelo teste de Tukey.

Em ambos os lotes, quando o condicionamento foi realizado em soluções aeradas de PEG a $-1,0 \mathrm{MPa}$ por oito dias e a $-1,2 \mathrm{MPa}$, por quatro e oito dias, houve incremento no comprimento da raiz primária das plântulas em relação à testemunha. Neste caso, o efeito do método de condicionamento foi mais expressivo do que nos demais testes realizados. Demir e Oztokat (2003) obtiveram acréscimos no tamanho da raiz primária de plântulas de melão com o tempo de condicionamento de 35 dias, afirmando que soluções aeradas facilitam o condicionamento por períodos mais longos. No presente trabalho, independente do potencial osmótico da solução, no período mais longo de condicionamento ( 8 dias) os efeitos da aeração foram mais pronunciados. Maior crescimento da raiz primária também 
foi constatado por Bittencourt et al. (2004) em sementes de aspargo osmocondicionadas em PEG 6000 a -1,0 por 14 dias. Para Smith e Cobb (1992), o condicionamento osmótico de sementes tem efeito positivo no desenvolvimento da raiz primária por promover incrementos nos níveis de DNA e RNA, no teor de proteínas solúveis, na taxa respiratória, na "síntese-de-novo" de enzimas específicas, o que proporcionaria maior acúmulo de solutos, resultando num crescimento mais rápido e maior acúmulo de biomassa.

\section{CONCLUSÕES}

O condicionamento osmótico em PEG 6000 por quatro dias aumentou a porcentagem e a velocidade de germinação e a emergência das plântulas de cenoura em campo;

Para o crescimento da raiz primária, o condicionamento osmótico em solução aerada em PEG 6000 a -1,2MPa foi superior ao tratamento em papel.

\section{REFERÊNCIAS}

AKERS, S.W.; BREDE, J.; BATES, J.J. Why some vegetables seeds cannot be primed in aerated solutions. HortScience, Alexandria, v.20, p.549, 1985.

BALBINOT, E.; LOPES, H.M. Efeitos do condicionamento fisiológico e da secagem na germinação e no vigor de sementes de cenoura. Revista Brasileira de Sementes, Pelotas, v.28, n.1, p.1-8, 2006.

BITTENCOURT, M.L.C.; DIAS, D.C.F.S.; DIAS L.A.S.; ARAÚJO, E.F. Efeito do condicionamento osmótico das sementes na germinação e no crescimento das plântulas de aspargo. Revista Brasileira de Sementes, Pelotas, v.26, n.1, p.50-56, 2004.

BRADFORD, K.J. Manipulation of seed water relations via osmotic priming to improve germination under stress conditions. HorScience, Alexandria, v.21, n.5, p.1105-1112, 1986.

BRASIL. Ministério da Agricultura e da Reforma Agrária. Regras para análise de sementes. Brasília, DF: SNDA/ DNDV/CLAV, 1992. 365p.

CANTLIFFE, D. J.; ABEBE, Y. Priming solarset tomato seeds to improve germination at high temperature. Proceedings of the Florida State Horticultural Society, Gainsville, v.106, n.1, p.177-183, 1993.

CANTLIFFE, D.J.; ELBALLA, M. Improved germination of carrot at stressful high temperature by seed priming. Proceedings of the Florida State Horticultural Societ, Gainsville, v.107, n.1, p.121-128, 1994.
CARNEIRO, J.W.P.; BRACINNI A.L.; GUEDES, T. A.; AMARAL, D. Influência do estresse hídrico, térmico e do condicionamento osmótico no desempenho germinativo de sementes de cenoura (Daucus carota L.). Revista Brasileira de Sementes, Brasília, v. 21, n. 2, p. 208-216, 1999.

CARVALHO, L. F.; MEDEIROS-FILHO, S.; ROSSETTI, A. G.; TEÓFILO, E.M. Condicionamento osmótico em sementes de sorgo. Revista Brasileira de Sementes, Londrina, v. 22, n.1, p.185-192, 2000.

CASEIRO, R.F.; BENNETT, M.A.; MARCOS FILHO, J. Comparison of three priming techniques for onion seed lots differing in initial seed quality. Seed Science and Technolog, Zurich, v.32, n.2, p.365-375, 2004.

CASEIRO, R.F.; MARCOS FILHO, J. Métodos para a secagem de sementes de cebola submetidas ao condicionamento fisiológico. Horticultura Brasileira, Brasília, v.23, n.4, p.887-892, 2005.

COPELAND, L.O.; McDONALD, M.B. Principles of seed science and technology. 3.ed. New York: Chapman \& Hall, 1995. 409p.

COSTA, C. J.; VILLELA, F.A. Condicionamento osmótico de sementes de beterraba. Revista Brasileira de Sementes, Pelotas, v.28, n.1, p.21-29, 2006.

DEMIR, I.; OZTOKAT, C. Effect of salt priming on germination and seedling growth at low temperatures in watermelon seeds during development. Seed Science and Technology, Zurich, v.31, n.3, p.765-770, 2003.

EVANS, T.A.; PILL, W.G. Emergence and seedling growth from osmotically primed or pregerminated seeds of asparagus (Asparagus officinalis L.). The Journal of Horticultural Science, Alexandria, v.64, n.3, p.275-282, 1989.

GIMENEZ-SAMPAIO, T.; SAMPAIO, N.V. Viabilidade, vigor e armazenamento de sementes de cenoura (Daucus carota L.) submetidas ao pré-condicionamento osmótico. Revista Científica Rural, Pelotas, v.3, n.1, p.38-45, 1998.

GRAY, D.; DREW, R. L. K.; BUJALSKI, W.; NIENOW, A. W. Comparison of polyethylene glycol polymers betaine and $\alpha$-proline for priming vegetable seed. Seed Science and Technology, Zarich, v.19, v.2, p.581-590, 1991.

GUEDES, A.C.; CANTLIFFE, D.J. Germination of lettuce seeds at high temperature after seed priming. Journal of the American Society for Horticultural Science, Alexandria, v.105, n.6, p.777-781, 1980.

HAIGH, A.M.; BARLOW, E.W.R.; MILTHORPE, F.L. Field emergence of tomato, carrot, and onion seeds primed in a aerated salt solution. Journal of the American Society 
for Horticultural Science, Alexandria, v.111, n.5, p.660$665,1986$.

HEYDECKER, W.; COOLBEAR, P. Seed treatments for improved performancesurvey and attempted prognosis. Seed Science and Technology, Zurich, v.5, n.2, p.353-425, 1977.

HEYDECKER, W.; HIGGIS, J.; TURNER, Y.J. Invigoration of seeds. Seed Science and Technology, Zurich, v.3, n.3, p.881-888, 1975.

KHAN, A.A. Preplant physiological seed conditioning. Horticultural Reviews, v.13, p.131-181, 1992.

KHAN, A.A.; TAO, K.L.; KNYPL, J.S.; BORKOWSKA, B.; POWELL, L.E. Osmotic conditioning of seeds: physiological and biochemical changes. Acta Horticulturae, Wageningen, v.83, p.267-283, 1978.

LOPES, H.M.; ROSSETTO, C.A.V.; CARNEIRO, V. Embebição de sementes de cenoura (Daucus carota L.) em diferentes potenciais osmóticos por dois métodos. Revista Brasileira de Sementes, Londrina, v. 22, n. 1, p.81-87, 2000.

MAGALHÃES, F. H. L.; MACHADO, J. C.; VIEIRA, M. G. G. C.; GUIMARÃES, R. M.; OLIVEIRA, J. A.; LEDO, C. A. S. Desempenho de sementes de cenoura portadoras de espécies de Alternaria após o condicionamento fisiológico com adição de Thiram. Ciência Agrotecnica, v.28, n.5, p.1007-1014, 2004.

MARCOS-FILHO, J. Fisiologia de sementes de plantas cultivadas. Piracicaba: FEALQ, 2005. 495p.

MAUDE, R.B.; DREW, R.L.K.; GRAY, D.; PETCH, G.M.; BUJALSKI, W.; NIENOW, A.W. Strategies for contol of seed-borne Alternaria dauci (leaf blight) of carrots in priming and process engineering systems. Plant Pathology, v.41, n.1, p.204-214, 1992.

NAKAGAWA, J. Testes de vigor baseados no desempenho das plântulas. In: KRZYZANOWSKI, F.C.; VIEIRA, R.D.; FRANÇA NETO, J.B.. (Ed.). Vigor de sementes: conceitos e testes. Londrina: ABRATES, 1999. p.2-1-224.

NASCIMENTO, W.M, Condicionamento osmótico de sementes de hortaliças, Brasília, Embrapa Hortaliças, 2004. 12 p. (Embrapa Hortaliças. Circular Técnica, 33).
NASCIMENTO, W.M. Muskmelon seed germination and seedling development in response to seed priming. Scientia Agricola, Piracicaba, v.60, n.1, p.71-75, 2003.

NASCIMENTO, W.M.; ARAGÃO, F.A.S. Condicionamento osmótico de sementes de melão: absorção de água e germinação sob diferentes temperaturas. Revista Brasileira de Sementes, Pelotas, v.24, n.1, p.153-157, 2002.

NUNES, U.R.; SANTOS, M.R.; ALVARENGA, E.M.; DIAS, D.C.F.S. Efeito do condicionamento osmótico e do tratamento com fungicida na qualidade fisiológica e sanitária de sementes de cebola (Allium cepa L.). Revista Brasileira de Sementes, Londrina, v.22, n.1, p.239-246, 2000.

PARERA, C.A.; CANTLIFFE, D.J. Presowing seed priming. Horticultural Reviews, v. 16, n.1, p. 109-141, 1994.

PELUZIO, L.E.; SILVA, R.F.; REIS, M.S.; CECON, P.R.; DIAS, D.C.F.S.; PELUZIO, J.B.E. Efeito do condicionamento osmótico na embebição e na germinação de sementes de cenoura (Daucus carota L.). Revista Brasileira de Sementes, Londrina, v.21, n.2, p.161-169, 1999.

SAS. SAS/STAT user's guide. Version 6, 4 ed. SAS Cary, NC, Institute Inc, 1989.

SMITH, P.T.; COBB, B.G. Physiological and enzimatic characteristics of primed, re-dried and germinated pepper seeds (Capsicum annum L.). Seed Science and Technology, Zürich, v.20, n.3, p.503-513, 1992.

THORNTON, J.M.; POWELL, A.A. Prolonged aerated hydration for the improvement of seed quality in Brassica oleracea L. Annals of Applied Biology, Warwick, v.127, p.183-189, 1995.

TRIGO, M.F.O.O.; NEDEL, J.L.; TRIGO, L.F.N. Condicionamento osmótico em sementes de cebola: II. Efeitos sobre o vigor. Revista Científica Rural, Pelotas, v.5, n.2, p.1-11, 2000.

VILLELA, F.A.; DONI FILHO, L.; SEQUEIRA, E.L. Tabela de potencial osmótico em função da concentração de polietileno glicol 6000 e da temperatura. Pesquisa Agropecuária Brasileira, Brasília, v.26, n.11/12, p.19571968, 1991.

WELBAUM, G.E; SHEN, Z.; OLUOCH, M.O.; JETT, L.W. The evolution and effects of priming vegetable seeds. Seed Technology, Lansing, v.20, n.2, p.209-235, 1998. 